\title{
Pengembangan Produk Kosmetika Berbahan Susu Kambing menjadi Sabun Cair
}

\author{
Formulating of Fresh Goat Milk Products into Liquid Soaps
}

Uswatun Chasanah ${ }^{*}$
Dyah Rahmasari ${ }^{2}$
1Department of Pharmacist
Professional Education, Universitas
Muhammadiyah Malang, Malang,
East Java, Indonesia
2Department of Pharmacy, Universitas
Muhammadiyah Malang, Malang,
East Java, Indonesia

email: uswatun@umm.ac.id
Kata Kunci
Formulasi
Sabun cair
Susu kambing segar
Keywords:
Formulations
Liquid soap
Fresh goat's milk
Received: August 2020
Accepted: January 2021
Published: February 2021

\begin{abstract}
Abstrak
Susu kambing kaya akan kandungan nutrisi terutama vitamin A dan asam laktat yang sangat bermanfaat untuk kesehatan kulit, oleh sebab itu sesuai untuk bahan sabun mandi cair namun dari cara pembuatan yang yang sudah diketahui umum diperlukan waktu lama. Telah dilaksanakan kegiatan Iptek bagi Masyarakat kepada sekelompok masyarakat di desa Torong rejo, kota Batu yang berprofesi sebagai produsen susu kambing segar. Kegiatan ini berupa kegiatan pelatihan pembuatan sabun cair yang mengandung susu kambing segar dengan metode yang sederhana dan singkat. Hasil dari kegiatan ini adalah terjadi peningkatan pengetahuan dan ketramplan peserta pelatihan sehingga mereka dapat memperkaya varian produk berbahan dasar susu kambing segar. Diharapkan dengan semakin bevariasinya produk berbahan susu kambing segar yang ditawarkan akan meningkatkan perekonomian peserta pelatihan.
\end{abstract}

\begin{abstract}
Goat's milk is rich in nutrients, especially vitamin A and lactic acid which are very beneficial for skin health, so it is suitable for liquid bath soap ingredients. However, well-known manufacturing takes a long time to make. Implemented training to producers of fresh goat's milk is formulating liquid soap made from fresh goat's milk that a simple method and quickly. The result of this activity is an increase in the knowledge and skills of participants so that they can enrich the variety of products based on fresh goat milk. It is hoped that with the increasing variety of goat milk products that they offer, there will be an increase in the economy of participants.
\end{abstract}

(c) 2021 Uswatun Chasanah, Dyah Rahmasari. Published by Institute for Research and Community Services Universitas Muhammadiyah Palangkaraya. This is Open Access article under the CC-BY-SA License (http://creativecommons.org/licenses/by-sa/4.0/). DOI: https://doi.org/10.33084/pengabdianmu.v6i2.1601

\section{PENDAHULUAN}

Susu kambing kaya akan lemak, protein, mineral, dan vitamin yang sangat bermanfaat bagi kulit (Yadav et al., 2016; Clark \& García, 2017). Kandungan asam lemak dalam susu kambing dapat melembabkan kulit, kandungan protein dalam susu kambing sebagai sumber nutrisi kulit, vitamin $\mathrm{A}$ dan $\mathrm{E}$ sebagai antioksidan, dan juga asam alfa hidroksi seperti asam laktat yang dapat mengelupas sel kulit mati dari permukaan kulit (Sepe \& Argüello, 2019; Purwati et al.,
2012). Kelompok petenak kambing yang berlokasi di desa Mojorejo kota Batu adalah Mitra dari program pengabdian. Kegiatan ini adalah memenuhi keinginan pihak Mitra untuk pembimbingan pembuatan sabun cair berbahan dasar susu kambing yang merupakan tindak lanjut dari pelatihan sebelumnya, yakni tentang pembuatan sabun padat berbahan susu kambing (Chasanah et al., 2020). Pada kenyataannya, sudah banyak tutorial pembuatan sabun cair berbahan susu kambing yang diunggah di media sosial, namun kebanyakan yang diunggah adalah menggunakan 
metode 'cold process' (Berry, 2014) yang memakan waktu lama sehingga dirasa kurang praktis. Mempertimbangkan hal tersebut maka Tim Pengabdian dari Universitas Muhammadiyah Malang menyelenggakan pelatihan formulasi sabun cair susu kambing secara langsung kepada pihak Mitra.

\section{METODOLOGI}

Terlebih dahulu disiapkan bahan dan alat yang diperlukan. Bahan-bahan yang harus disiapkan adalah susu kambing segar, Sodium Lauryl Sulfas (SLES), Garam (Natrium Klorida), Glyseril stearat, Cocomide DEA, DMDM hydantoin, parfum, dan air. Semua bahan ini kecuali susu dan air diperoleh dari toko kimia. Sedangkan untuk peralatannya adalah gelas ukur plastik berbagai ukuran, timbangan, dan alat pemanas.

Pelaksanaan kegiatan dimulai dari pengarahan oleh Tim pengabdian. Materi pada saat pengarahan adalah meliputi fungsi dari bahan-bahan pembuat sabun, juga alasan mengapa urutan pembuatan harus sedemikain rupa, setelah itu dilanjutkan dengan pembuatan sabun cair oleh masing-masing peserta yang telah diberikan satu paket bahan untuk membuat sabun cair $500 \mathrm{~mL}$. Guna mempermudah peserta, maka disediakan tutorial formulasi sabun cair susu kambing yang khusus dibuat untuk mendukung kegiatan ini. Tutorial tentang pembuatan sabun cair susu kambing telah diunggah pada media sosial melalui kanal https://youtu.be/V6PuCDUe7I.

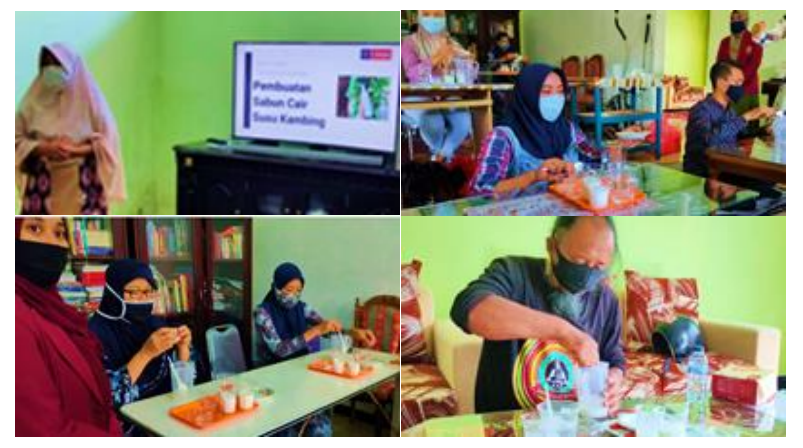

Gambar 1. Kegiatan pelatihan

\section{HASIL DAN PEMBAHASAN}

Kegiatan pelatihan formulasi sabun cair susu kambing ini adalah merupakan tindak lanjut dari pelatihan sebelumnya tentang formulasi sabun padat dari susu kambing. Pada kegiatan kali ini juga mendapat respon yang sangat baik dari semua peserta, mereka puas dengan metode yang digunakan karena mudah dan singkat. Teknis pencampuran yang merupakan hasil beberapa kali uji coba Tim pengabdian telah menghasilkan bentuk sabun cair yang baik. Jika dibandingkan dengan cara pembuatan sabun cair susu kambing dengan menggunakan cara cold process yang perlu waktu lebih lama dan energi lebih banyak, tentulah cara yang diplih di pelatihan ini jauh lebih baik.

Hasil testimoni dari peserta pelatihan menyatakan bahwa saat digunakan didapatkan bentuk busa yang lembut atau creamy, mudah dibilas, dan memiliki efek yang melembabkan. Penggunaan bahan tambahanSLES sebagai surfaktan non ionik tidak mengakibatkan iritasi kulit (Anggraeni et al., 2020). Natrium Klorida adalah untuk meningkatkan viskositas SLES, juga penambahan glyceryl stearat mempercantik penampilan sabun menjadi putih dengan hasil busa lebih creamy (Elder, 1982). Cocomide DEA sebagai pembentuk busa seperti halnya SLES (Prayadnya et al., 2017) akan memberikan sensasi bahwa sabun cair ini memiliki daya bersih, sedangkan gliserin memberikan rasa lembut pada kulit (Becker et al., 2019).

Hal lain yang menarik dari rangkaian pelatihan ini adalah bahwa harga bahan-bahan untuk membuat sabun ini adalah murah sehingga berpeluang untuk dijual dengan harga yang ekonomis. 


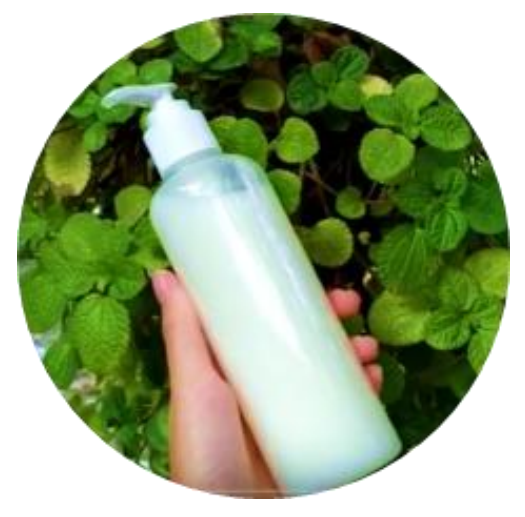

Gambar 2. Sabun cair susu kambing

\section{KESIMPULAN}

Pelatihan formulasi sabun cair susu kambing segar sangat bermanfaat bagi pihak Mitra karena akan memperkaya varian produk yang mereka tawarkan. Untuk selanjutnya akan diadakan kegiatan pelatihan sediaan krim dari keffir susu kambing segar guna memfasilitasi permintaan dari Mitra.

\section{UCAPAN TERIMA KASIH}

Terimakasih kepada Universitas Muhammadiyah Malang yang telah memberikan bantuan pendanaan melalui Blok Grand Fakultas Ilmu Kesehatan Universitas Muhammadiyah Malang Tahun Anggaran 2019/2020, Bapak Ferdiansyah yang telah membantu merancang formulasi sabun cair susu kambing, dan para mahasiswa yang telah membantu kegiatan pelatihan.

\section{REFERENSI}

Anggraeni, Y., Nisa, F., Betha, O.S. 2020. Karakteristik Fisik dan Aktivitas Antibakteri Sabun Cair Minyak Nilam (Pogostemon cablin Benth.) yang Berbasis Surfaktan Sodium Lauril Eter Sulfat. Jurnal Kefarmasian Indonesia. 10(1):1-10. https://doi.org/10.22435/jki.v10i1.499

Becker, L.C., Bergfeld, W.F., Belsito, D.V., Hill, R.A., Klaassen, C.D., Liebler, D.C., Marks, J.G., Shank, R.C., Slaga, T.J., Snyder, P.W., Gill, L.J., Heldreth, B. 2019. Safety Assessment of Glycerin as Used in Cosmetics. International
Journal of Toxicology. 38(3_suppl):6S-22S. https://doi.org/10.1177/1091581819883820

Berry, J. 2014. How to Make Soap with Milk. Available at: https://thenerdyfarmwife.com/how-tomake-soap-with-milk/

Chasanah, U., Rahmasari, D., Titani, M. 2020. IbM Pelatihan Formulasi Sabun Padat Susu Kambing. PengabdianMu: Jurnal Ilmiah Pengabdian Kepada Masyarakat. 5(2):133-137. https://doi.org/10.33084/pengabdianmu.v5i 2.1035

Clark, S., García, M.B.M. 2017. A 100-Year Review: Advances in goat milk research. Journal of Dairy Science. 100(12):10026-10044. https://doi.org/10.3168/jds.2017-13287

Elder, R.L. 1982. Final Report on the Safety Assessment of Glyceryl Stearate and Glyceryl Stearate/SE. Journal of the American College of Toxicology. 1(4):169-192.

https://doi.org/10.3109/10915818209021268

Prayadnya, I.G.Y., Sadina, M.W., Kurniasari, N.L.N.N., Wijayanti, N.P.D., Yustiantara, P.S. 2017. Optimasi Konsentrasi Cocamid Dea Dalam Pembuatan Sabun Cair Terhadap Busa Yang Dihasilkan Dan Uji Hedonik. Jurnal Farmasi Udayana. 6(1):11-14. https://doi.org/10.24843/JFU.2017.v06.i01.p 03

Purwati, E., Vebriyanti, E., Suharto, E.L.S. 2012. Sabun Susu Kambing Virgin Coconut Oli Dapat Meningkatkan Kesehatan Kulit Melalui pH dan Bakteri Baik (Bakteri Asam Laktat) serta Meningkatkan Pendapatan Masyarakat. In Prosidimh Seminas Competitive Advantage II, Universitas Pesantren Tinggi Darul ‘Ulum. 1(2):1-7.

Sepe, L., Argüello, A. 2019. Recent advances in dairy goat products. Asian-Australasian Journal of Animal Sciences. 32(8):1306-1320. https://dx.doi.org/10.5713/ajas.19.0487

Yadav, A.K., Singh, J., Yadav, S.K. 2016. Composition, nutritional and therapeutic values of goat milk: A review. Asian Journal of Dairy and Food Research. 35:96-102. http://dx.doi.org/10.18805/ajdfr.v35i2.10719 